\title{
PEMBELAJARAN MODEL CONTEXTUAL TEACHING AND LEARNING DENGAN MEMANFAATKAN LINGKUNGAN SEBAGAI SUMBER BELAJAR IPS DALAM MENINGKATKAN PRESTASI BELAJAR SISWA
}

\author{
Harry Surahman \\ IKIP Budi Utomo Malang \\ surahman.harry@yahoo.co.id
}

\begin{abstract}
Education in Indonesia is still dominated by the view that knowledge of the facts that must be memorized. This has resulted in students becoming passive learners. Therefore, teachers are expected to select and apply the learning model appropriate to the situation and condition of learning. This is done to avoid failing students in learning, due to a lack of understanding of the concept as a whole. Contextual Teaching and Learning (CTL), as the concept of learning strategies that help teachers link between what is taught by the empirical facts known to the students and encourage students to create relationships through the application of knowledge in everyday life. The problem in this study are: (1) Learning by Utilizing CTL Model Environment as a Learning Resource IPS experimental class could be better than the conventional model in classroom learning control (2) Is the student response to learning with the use CTL as the Source of Learning Environment IPS better than Using Conventional.The design of such studies are experimental research with two groups pretest-posttest design. The subjects were students of class VII SMP Yadika Bangil Pasuruan the number of 25 students for each class experimental and control classes. The instrument used to collect data include questionnaires, achievement test, observation, and documentation. Data analysis using SPSS 17 software. Based on a statistical analysis of the study showed that there is a significant difference between the improvement of student learning outcomes in the classroom experiments with the control class. In more detail the following results were obtained: (1) The results show completeness minimal thorough standart (KKM) student learning after the learning process using CTL model to use the environment as a source of social studies with a completeness of $88 \%$, (2) the activity of the students participating in learning activities with CTL using the environment as a learning resource better than the students who take conventional learning, (3) Students responded positively to the application of learning CTL model by using the environment as a source of learning, (4) barriers were found during the study that although a small percentage of his lack of time (lesson 2 hours $x 40$ minutes) so that students who have not completed the task in school serve as homework. Based on these findings it can be concluded that the CTL model by using the environment as a learning resource in learning the topic of population and economic activity patterns of land use based on the physical condition of the Earth's surface can improve student learning outcomes SMP Yadika Bangil.
\end{abstract}

Keywords: Learning Contextual Teaching and Learning, Environment as a learning resource, Learning Outcomes

Dalam kehidupan suatu Negara, pendidikan memegang peranan yang sangat penting untuk menjamin kelangsungan hidup negara dan bangsa, karena pendidikan merupakan wahana untuk meningkatkan dan mengembangkan kualitas Sumber Daya Manusia (Mulyasa, 2003:15). Dalam implementasinya, saat ini pendidikan di Indonesia masih didominasi oleh pandangan bahwa pengetahuan sebagai perangkat fakta-fakta yang harus di hafal.

Berdasarkan kenyataan proses pembelajaran di sekolah yang bersifat konvensional dalam arti guru menyampaikan materi pelajaran hanya dengan berceramah (teacher centered) sehingga peran guru sangat dominan dan siswa tidak pernah terlibat langsung dalam proses pembelajaran. Siswa menjadi peserta didik yang pasif karena mereka hanya membayangkan materi pelajaran yang diajarkan tanpa adanya pemahaman konsep yang dibangun sendiri oleh siswa. Belajar akan lebih bermakna jika anak mengalami apa yang dipelajarinya, bukan mengetahuinya. Pembelajaran yang berorientasi pada penguasaan materi terbukti berhasil dalam kompetisi mengingat jangka pendek tetapi gagal dalam membekali anak memecahkan persoalan dalam kehidupan jangka panjang.

Padahal seharusnya pembelajaran merupakan suatu proses kegiatan belajar 
mengajar yang berkaitan dengan menciptakan lingkungan belajar yang nyaman dan efektif. Menciptakan lingkungan belajar yang baik sejalan dengan pernyataan Gagne, dkk (1979) bahwa pembelajaran adalah menciptakan lingkungan agar dapat mempengaruhi siswa untuk aktif belajar, jadi penekanannya disini adalah aktivitas siswa untuk belajar. Sedangkan menurut Undang-Undang No. 20 Tahun 2003 pembelajaran adalah proses interaksi peserta didik dan sumber belajar pada suatu lingkungan belajar. Dengan demikian lingkungan belajar yang baik dapat mempengaruhi keberhasilan siswa dalam belajar.

\section{Ilmu Pengetahuan Sosial (IPS)} merupakan salah satu disiplin ilmu yang diajarkan di sekolah menengah dan erat kaitannya dengan masalah kehidupan sosial dan lingkungan masyarakat di sekitar siswa. IPS pada tingkat sekolah menengah merupakan ilmu yang mempelajari kehidupan sosial yang bahan kajiannya bersumber dari ekonomi, sejarah, geografi, dan sosiologi. Keterpaduan ilmu-ilmu sosial dalam mata pelajaran IPS, dapat dimaknai bahwa kandungan atau muatan bahan pembelajaran IPS bersumber pada kegiatan yang erat kaitannya dengan aktivitas dalam kehidupan manusia dan hal itu sangat relevan untuk mengembangkan potensi dalam kehidupan siswa. Dengan belajar IPS di sekolah menengah diharapkan dapat terbentuk potensi yang berupa kepribadian, memperluas wawasan, dan menambah pengalaman pada siswa. Hal ini sejalan dengan esensi IPS, yaitu dapat bermuara pada terwujudnya pemanusiaan generasi bangsa yang memiliki kemampuan dasar pada aspek kognitif, afektif, dan psikomotorik. Pemanusiaannya berangkat dari kemampuan awal menghadapi unsur-unsur kebudayaan lokal yang berwujud benda, perilaku, ide, dan nilai-nilai. Esensi pendidikan menengah itu relevan pada misi pembelajaran IPS.

Belajar IPS berarti belajar mengenai kenyataan-kenyataan sosial serta mengembangkan pengetahuan, sikap, dan ketrampilan-ketrampilan yang diperlukan untuk membantu mewujudkan kemanusiaan yang penuh dengan kecerdasan dan kemajuan. Dengan potensi tersebut, maka misi dalam pembelajaran IPS sangat relevan diimplementasikan secara formal di pendidikan menengah. Mencermati tujuan dan misi pembelajaran IPS, khususnya di sekolah menengah maka secara ideal guru SMP telah memiliki wawasan dan pengetahuan tentang konsep pembelajaran IPS yang diharapkan dapat menciptakan lingkungan belajar yang efektif. Menciptakan lingkungan belajar yang efektif akan dapat terwujud jika tujuan dan misi pembelajaran IPS diimplemantasikan secara nyata.

Sumber belajar berupa lingkungan di sekitar siswa dapat dijadikan sebagai sumber belajar IPS dengan mengamati secara langsung pada objeknya. Pengamatan secara langsung terhadap objek belajar merupakan aplikasi konkret dalam pembelajaran. Penggunaan lingkungan sekitar sebagai sumber belajar IPS dapat mengaktifkan siswa dalam proses belajar. Lingkungan di sekitar siswa dan lingkungan yang dapat dijangkau harus didayagunakan oleh guru dan siswa agar tercipta proses belajar mengajar yang baik. Guna menciptakan interaksi siswa dengan lingkungan mereka dalam pembelajaran IPS diperlukan pendekatan yang berbasis aktivitas berinteraksi dengan lingkungan. Pendekatan yang sesuai adalah pembelajaranCTL dengan lingkungan sebagai sumber belajar.Pembelajaran secara kontekstual berhubungan dengan (1) fenomena kehidupan sosial masyarakat, bahasa, lingkungan hidup, harapan dan cita yang tumbuh, (2) fenomena dunia pengalaman dan pengetahuan murid, dan (3) kelas sebagai fenomena sosial. Kontekstualitas merupakan fenomena yang bersifat alamiah, tumbuh dan terus berkembang, serta beragam karena berkaitan dengan fenomena kehidupan sosial masyarakat. CTLpada pembelajaran IPS dapat berdampak pada aktivitas memanfaatkan lingkungan sebagai sumber belajar dalam pembelajaran IPS. Dengan memanfaatkan lingkungan sebagai sumber belajar dalam pembelajaran IPS dapat menjembatani pembentukan pengalaman, pengetahuan, sikap, dan ketrampilan dalam berbagai segi kehidupan.

Pendekatan Contextual Teaching and Learning (CTL) merupakan konsep belajar yang membantu guru mengaitkan antara materi yang diajarkan dengan situasi dunia nyata siswa dan mendorong siswa membuat hubungan antara 
pengetahuan yang dimilikinya dengan penerapannya dalam kehidupan mereka sebagai anggota keluarga dan masyarakat. Dengan demikian hasil pembelajaran diharapkan lebih bermakna bagi siswa. Proses pembelajaran berlangsung alamiah dalam bentuk kegiatan siswa bekerja dan mengalami, bukan mentransfer pengetahuan dari guru ke siswa. Strategi pembelajaran lebih dipentingkan daripada hasil.

Berdasarkan hasil pengamatan dan wawancara kepada Kepala Sekolah SMP Yadika Bangil Pasuruan, terungkap bahwa di lingkungan kecamatan Bangil (SMP Yadika Bangil Pasuruan) sangat kaya akan sumber belajar untuk dapat dimanfaatkan pada berbagai mata pelajaran, misalnya dalam mata pelajaran IPS dapat berupa lingkungan, rumah, pertokoan, pasar, tempat-tempat bersejarah, perkantoran pemerintah atau swasta seperti kantor pos, kantor polisi, bank Mandiri, bank BPD Jatim, bank BRI, bank BCA dan lain-lain.

Bangil terletak diantara jalan akses dari Surabaya menuju Banyuwangi dan Bali, serta mempunyai jalur alternatif yang bisa menghubungkan kita dengan cepat ke Pandaan, Sukorejo serta Malang. Kota Bangil sangat padat penduduknya dengan berbagai suku dan etnis, diantaranya Jawa, Tionghoa, Arab Banjar, Madura dan lainnya. Hidup saling berdampingan dan saling menghargai satu sama lain.

Dari paparan lingkungan tersebut sayang sekali jika guru dalam mengevaluasi hasil belajar lebih menekankan pada "mengingat dan memahami" sangat dominan, sehingga pola dan kemampuan berpikir seorang ilmuwan dan proses internalisasi masih diabaikan. Kemudian kurang idealnya pembelajaran IPS di SMP dewasa ini juga disebabkan potensi tingkat pengetahuan siswa, yaitu hanya membina taksonomi kawasan rendah yakni hafalan. Selain itu dari pihak siswa, terungkap bahwa dalam belajar IPS sebagai mata pelajaran yang membosankan, lunak, gampang, dan bisa dipelajari dalam beberapa hari menjelang ujian.

Gambaran di atas menunjukkan bahwa pembelajaran IPS, khususnya di SMP belum terlaksana secara optimal. Belum optimalnya pembelajaran tersebut, karena IPS belum dirancang sesuai kebutuhan dan minat siswa. Selain itu, dalam pembelajaran IPS guru kurang memanfaatkan potensi lingkungan sekitar siswa sebagai sumber belajar. Potensi pemanfaatan lingkungan yang ada tergantung pada guru yang memanfaatkannya. Hasil pengamatan pembelajaran di kelas yang dilakukan oleh peneliti, menunjukkan bahwa dalam proses pembelajaran IPS masih tampak mendominasi guru dalam interaksi belajar. Pemanfaatan sumber belajar IPS masih cenderung berpusat pada guru.

Berdasarkan uraian diatas maka peneliti bermaksud melakukan penelitian tentang Pembelajaran Model CTL dengan Memanfaatkan Lingkungan sebagai Sumber Belajar IPS (studi di kelas 7 SMP YADIKA Bangil Pasuruan). Dengan potensi yang dimiliki oleh sekolah terteliti, cukup representatif, akomodatif, dan memiliki peluang memanfaatkan potensi lingkungan sekitar sebagai sumber belajar dalam pembelajaran, khususnya mata pelajaran IPS.

\section{METODE}

Penelitian ini tergolong Eksperimental Semu. Sugiyono (2009: 72) mengemukakan bahwa eksperimental semu mempunyai kelompok kontrol, tetapi tidak dapat berfungsi sepenuhnya untuk mengontrol variabel-variabel luar yang mempengaruhi pelaksanaan eksperimen. Jenis penelitian ini menggunakan desain penelitian two group prettest-posttest only control design. Untuk melakukan penelitian eksperimen, sebuah cara harus ditempuh yang dikenal dengan nama desain eksperimen, yaitu suatu rancangan percobaan sedemikian rupa sehingga informasi yang berhubungan dengan atau diperlukan untuk persoalan yang sedang diteliti dapat dikumpulkan. Desain eksperimen dalam penelitian ini dilakukan terhadap dua kelompok siswa yang diberi perlakuan berbeda dengan materi pelajaran yang sama. Untuk kelompok eksperimen digunakan CTL dalam penyampaian materi, sedang kelompok kontrol menggunakan pembelajaran konvensional. Hal ini dilakukan dengan harapan agar dapat diketahui secara lebih jelas dan konkrit efek penggunaan CTL yang dikontrol dengan pembelajaran konvensional terhadap peningkatan hasil belajar siswa. 


\section{HASIL DAN PEMBAHASAN}

\section{Analisis Data Respon Siswa}

Respon siswa dianalisis menggunakan skala Likert dengan kategori: sangat tidak setuju, tidak setuju, setuju, sangat setuju. Penilaiannya untuk setiap jawaban sangat tidak setuju diberi skor 1, tidak setuju diberi skor 2, setuju diberi skor 3 , sangat setuju diberi skor 4 . Presentase tiap kategori dihitung dengan cara jumlah respon siswa tiap aspek dibagi dengan skor maksimal dikalikan dengan $100 \%$ kemudian disajikan dalam bentuk diagram batang/polygon. Jika siswa yang aktif lebih dari $60 \%$ maka dianggap seluruh siswa mempunyai respon yang positif terhadap pernyataan tersebut.

1. Analisis kendala yang dihadapi dalam memanfaatkan lingkungan sebagai sumber belajar

Untuk mengetahui hambatan atau kendala apa saja yang dihadapi oleh guru dalam memanfaatkan lingkungan sebagai sumber belajar digunakan lembar pengamatan dan hasilnya diuraikan dalam bentuk deskriptif.

2. Analisis Ketuntasan Belajar

Analisis ketuntasan atau ketercapaian pembelajaran siswa dinyatakan dalam persentase. Siswa dinyatakan tuntas hasil belajarnya (ketuntasan individu) apabila telah mencapai nilai 70 sebagai batas penguasaan materi. Untuk ketuntasan klasikal, dikatakan tuntas belajarnya bila dalam kelas tersebut terdapat e" $70 \%$ siswa tuntas belajarnya.

Untuk mengetahui hasil dari penelitian ini di peroleh dari Data Primer yakni Tes Hasil Belajar, Observasi dan Kuesioner yang disebarkan kepada 50 orang (25 orang untuk kelompok eksperimen dan 25 orang untuk kelompok kontrol). Analisis data sekunder didasarkan pada hasil pengamatan di lapangan yang berupa lembar pengamatan. Hambatan selama peneliti melakukan penelitian dan beberapa sumber pustaka untuk memperkuat dan memperdalam hasil analisis.

Data primer adalah sejumlah skor yang diperoleh dari jawaban responden atas pertanyaan atau pernyataan mengenai variabel penelitian, yaitu respon siswa dan tes hasil belajar dari kelompok eksperimen.data tersebut diperoleh melalui instrumen penelitian yakni Tes
Hasil Belajar dan Angket. Variabel tersebut dianalisis dengan menggunakan statistik deskriptif dan analisis komparatif uji t.

Data responden yang diperoleh melalui kuesioner dianalisis secara deskriptif. Data lain yang diperoleh dari studi pustaka akan digunakan sebagai data sekunder untuk melengkapi dan mendukung data primer.Analisis data sekunder didasarkan pada hasil pengamatan di lapangan dan beberapa sumber pustaka untuk memperkuat dan memperdalam hasil analisis.

Pada kelas uji coba dimana ada 25 siswa, yang dibagi menjadi lima kelompok yang semuanya diberi perlakuan dengan CTL. Setelah dibagi menjadi lima kelompok, tiap kelompok diberi tugas untuk mengamati kegiatan di sekitar sungai Kedung Larangan Kecamatan Bangil, kemudian mengambil data dari hasil pengamatan yang sudah dilakukan. Selanjutnya siswa dapat melaporkan apa yang telah diamati. Obyek yang diamati siswa adalah sungai Kedung Larangan di antara kelurahan Kersikan dan kelurahan Gempeng, yang letaknya tidak jauh dari lingkungan siswa, yaitu mempunyai jarak \pm 100 meter dari sekolah. Berdasarkan hasil pengamatan yang dilakukan siswa pada 29 Mei 2013 diperoleh data-data kegiatan dan aktivitas di sekitar lingkungan sungai, diantaranya adalah tempat memancing, menjala ikan, menjaring ikan, tempat pembuangan sampah, tempat penggembalaan kambing, tempat pemakaman, dijadikan lahan untuk tanam menanam tanaman yang menghasilkan seperti Pisang, Ubi-Ubian, Pohon Jati, Pohon Randu (Pohon Kapuk), Bambu, Tebu, Pohon Jeruk Nipis, Pohon Blimbing. Untuk berjualan dengan mendirikan warung di sekitar bantaran sungai, di jadikan tempat pemukiman di sekitar sungai oleh warga. Sementara itu langkah-langkah inquiry yang digunakan dalam penelitian ini meliputi observing, inventaritation, dan communicating.

Untuk mengetahui Indeks Validitas Tes Hasil Belajar menggunakan rumus Corrected Item-total Correlation dari Pearson. Kriteria pengujian dilakukan bila korelasi tiap faktor positif dan besarnya 0,3 ke atas maka faktor tersebut merupakan construct yang kuat, sebaliknya bila harga korelasi di bawah 0.3 , maka dapat disimpulkan bahwa butir instrumen tersebut tidak valid, sehingga harus diperbaiki atau dibuang (Sugiyono, 2008:126). Pengujian 
juga dapat dilakukan dengan membandingkan nilai $r$ hitung dengan $r$ tabel, dimana sebuah item instrumen dikatakan valid apabila mempunyai nilai korelasi lebih besar dari $r$ tabel (Sugiyono, 2008:128).

Dalam hasil penelitian Nilai Validitas atau Corrected Item-total Correlation untuk masingmasing variabel memiliki nilai $\mathrm{r}$ hitung lebih besar dari 0,3. Nilai $r$ hitung $>\mathrm{r}_{\text {tabel }_{(\mathrm{n}-2)}}$ dimana $r$ tabel $_{(23)}$ sebesar 0,39. Dengan demikian item pernyataan/pertanyaan dari Variabel Tes Hasil Belajar Siswa untuk Kelompok Eksperimen dan Kelompok Kontrol dinyatakan valid dan selanjutnya dapat digunakan dalam penelitian.

Berdasarkan hasil Uji Validitas soal kepada siswa anak SMP kelas VII sebanyak 25 orang, diperoleh bahwa dari 50 soal yang diujikan hanya ada 30 soal yang layak digunakan, sementara 20 soal yang lainnya tidak layak digunakan. Dengan kata lain hanya ada 30 soal yang digunakan dalam penelitian ini terhadap 25 siswa Kelompok Kontrol dan Kelompok Eksperimen yang diteliti.

Untuk mengukur Reliabilitas atau konsistensi internal diantara butir-butir pertanyaan dalam suatu instrumen dihitung dengan rumus koefisien alpha atau cronbach's alpha menggunakan software.Berdasarkan Malhotra (2002:282) item pengukuran dikatakan reliabel jika memiliki nilai koefisien alpha lebih besar dari 0,7.

Hasil penelitian juga menunjukkan bahwa nilai reliabilitas konsistensi internal, untuk koefisien alpha masing-masing variabel dalam setiap variabel dinyatakan reliabel karena lebih besar dari 0,7. Dengan demikian item pengukuran pada masing-masing variabel dinyatakan reliabel karena nilai $r_{11}$ sebesar 0.86 jauh di atas 0.7 dengan kategori tinggi.

Analisis data deskriptif pada penelitian ini bertujuan untuk memberikan gambaran atau penjelasan mengenai objek penelitian berdasarkan data dan variabel yang diperoleh dari kelompok subjek yang diteliti. Untuk memudahkan penulis dalam mendeskripsikan atau menginterpretasikan hasil penelitian yang dikemas dalam setiap tabel, maka penulis mengacu kalimat penafsiran data yang dikemukakan Arikunto (1998: 246), sebagai berikut:
$0 \%$

$1-25 \%$

$26-49 \%$

$50 \%$

$51-76 \%$

$77-99$

$100 \%$

: Tidak seorangpun dari siswa

: Sangat sedikit dari siswa

:Sebagian kecil/hampir setengah dari siswa

: Setengah dari siswa

: Sebagian besar dari siswa

: Hampir seluruh dari siswa

: Seluruh siswa

Kemudian jawaban siswa atas sejumlah tes hasil belajar, respons siswa terhadap kegiatan pembelajaran serta hasil pengamatan terhadap aktivitas siswa dalam kegiatan pembelajaran yang dihimpun lewat alat tes, angket dan lembar pengamatan dianalisis secara deskriptif persentase. Data tersebut kemudian dikemas dan ditampilkan dalam bentuk tabel distribusi frekuensi, dan grafik.

Berdasarkan Matriks Ketuntasan Individual danKlasikalTes Hasil Belajar dengan Model Pembelajaran CTL dengan Memanfaatkan Lingkungan sebagai Sumber Belajar bahwa nilai rata-rata pretes pada kelompok kontrol sebesar 46.40 sementara pada postes meningkat menjadi 55.87. Pada kelompok eksperimen terlihat bahwa nilai yang diperoleh pada pretes yaitu 50.80 sementara pada postes nilai mencapai 76.40. untuk melihat lebih jelas mengenai persentase ketuntasan hasil belajar pada kelompok kontrol dan kelompok eksperimen dapat disajikan pada Pretest dan Postest Ketuntasan Belajar pada Kelompok Kontrol.

Pada hasil pretes ketuntasan belajar pada kelompok eksperimen, lebih dari setengah siswa (84\%) tidak tuntas, dan tidak mencapai sepertiga dari seluruh siswa (16\%) siswa yang tuntas. Namun setelah mendapat perlakuan pembelajaran model CTL dengan memanfaatkan lingkungan sebagai sumber belajar, ternyata pada hasil Postest terjadi peningkatan ketuntasan hasil belajar pada kelompok eksperimen yaitu hampir seluruh siswa (88\%) yang tuntas dalam belajar. Dengan demikian, penerapan pembelajaran model CTL dengan memanfaatkan lingkungan sebagai sumber belajar dalam pembelajaran IPS dapat meningkatkan hasil belajar siswa.

Dari hasil penelitian berupa angket dan pengamatan dapat disimpulkan bahwa hasil postest kelompok eksperimen lebih tinggi dibandingkan dengan hasil postest kelompok kontrol. Selanjutnya untuk dapat menguatkan 
pernyataan di atas terkait ketuntasan hasil belajar siswa pada kelompok kontrol dan kelompok eksperimen maka dilakukan analisis perbandingan jumlah soal yang berhasil dijawab siswa dengan kategori tuntas pada kelompok eksperimen dan kelompok kontrol yang disajikan dalam bentuk grafik perbandingan antar kedua kelompok siswa tersebut seperti tampak pada gambar 4.1.

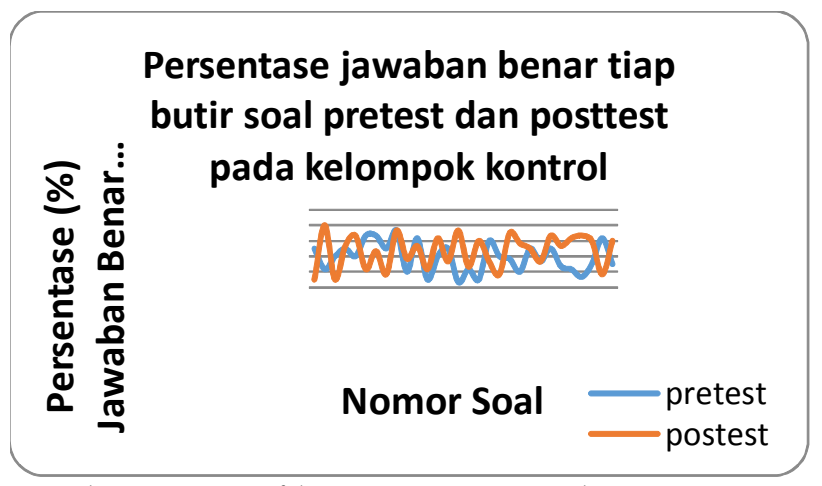

Gambar 4.1 Grafik Persentase Jawaban Benar Tiap Butir Soal Pretest dan Posttes pada Kelompok Kontrol.

Dari grafik pada Gambar 4.1, terlihat bahwa siswa yang menjawab benar ketika pretest maupun posttest pada kelompok kontrol tidak memperlihatkan perbedaan yang berarti. Secara umum dapat terlihat dari garis persentase jawaban benar ketika pretes tidak jauh berbeda dengan dengan postest. Jumlah jawaban yang benar disetiap pertanyaan pada waktu postest tidak jauh berbeda dengan jumlah jawaban yang benar pada setiap pertanyaan ketika pretes. Sehingga dapat disimpulkan bahwa secara umum tidak terdapat peningkatan hasil belajar siswa pada kelompok kontrol yang menggunakan model pembelajaran konvensional.

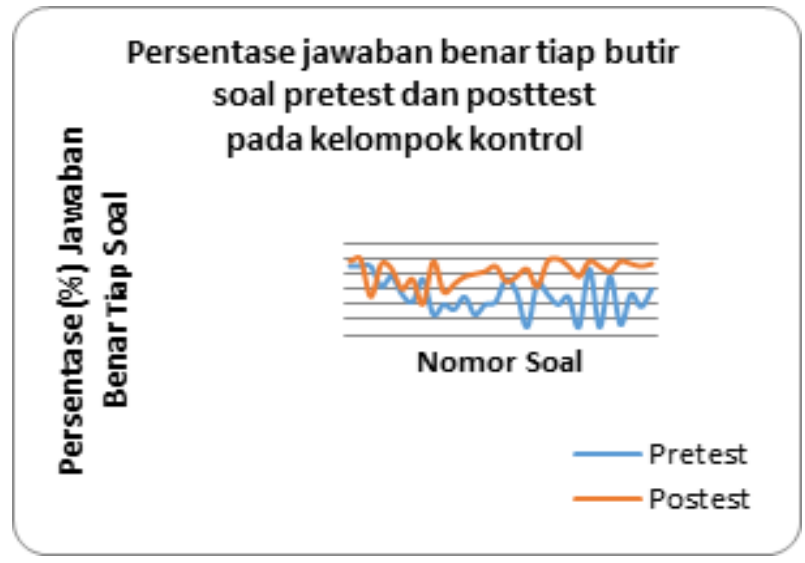

Gambar 4.2 Grafik Persentase Jawaban Benar Tiap Butir Soal Prettest dan Posttest pada Kelompok Eksperimen.

Grafik pada Gambar 4.2 memperlihatkan bahwa presentase siswa yang menjawab benar ketika pretes maupun postes terdapat adanya perbedaan yang berarti. Secara umum dapat terlihat dari garis persentase jumlah jawaban benar ketika postest berada di atas garis pretes. Jumlah jawaban yang benar pada setiap pertanyaan soal postest lebih tinggi dibandingkan dengan jumlah jawaban yang benar pada setiap pertanyaan soal pada waktu pretes. Sehingga dapat ditarik kesimpulan bahwa secara umum terdapat peningkatan hasil belajar siswa setelah mendapat perlakuan pembelajaran model CTL dengan memanfaatkan lingkungan sebagai sumber belajar.

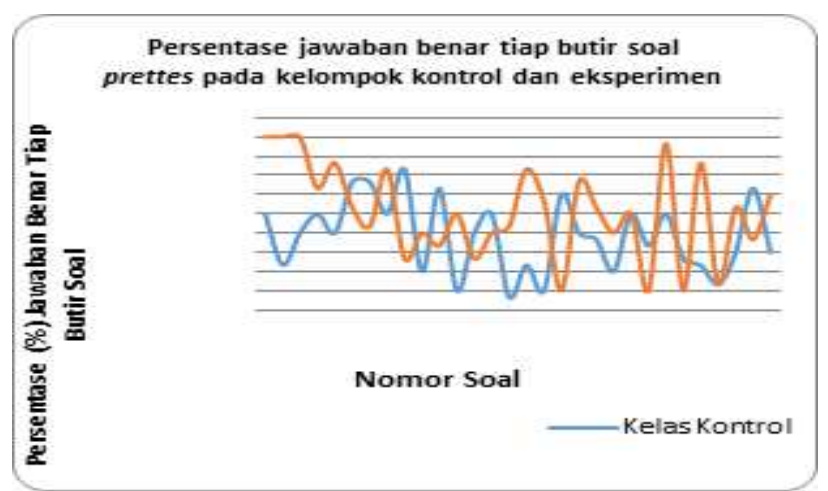

Gambar 4.3 Grafik persentase Jawaban Benar Tiap Butir Soal Prettes pada Kelompok Kontrol dan Kelompok Eksperimen

Dari grafik pada Gambar 4.3 di atas, terlihat bahwa persentase siswa yang menjawab benar ketika pretes pada kelompok kontrol dan kelompok eksperimen, memperlihatkan hampir tidak ada perbedaan yang berarti. Secara umum dapat terlihat dari garis pretes pada kelompok eksperimen berada di atas kelompok kontrol. Pada waktu pretes jumlah jawaban yang benar dari masing-masing pertanyaan pada kelompok eksperimen tidak jauh berbeda dengan jawaban pada kelompok kontrol.

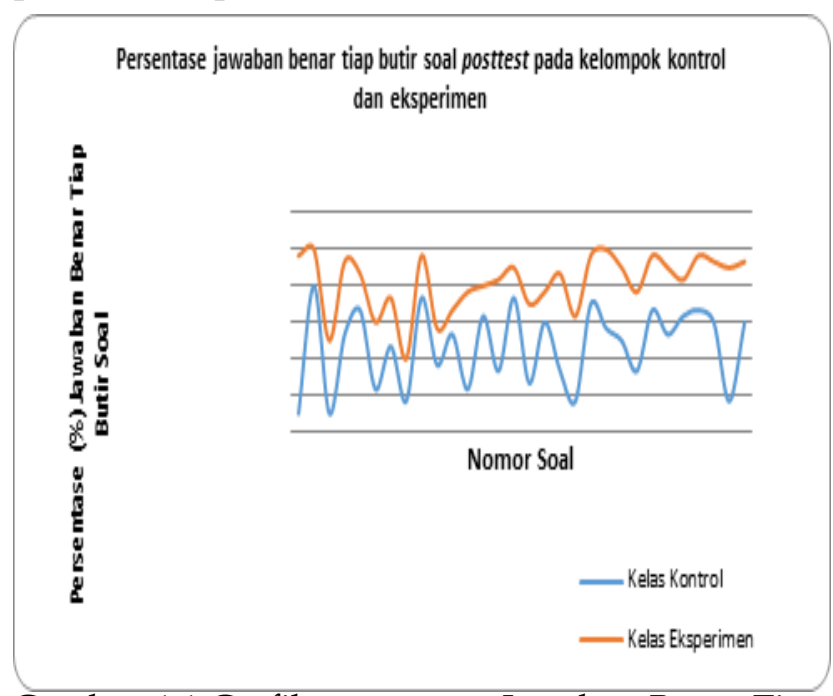

Gambar 4.4 Grafik persentase Jawaban Benar Tiap Butir Soal Prettes dan Posttes pada Kelompok Eksperimen 
Dari grafik pada Gambar 4.4 di atas, terlihat bahwa presentase siswa yang menjawab benar ketika postest pada kelompok kontrol dan kelompok eksperimen, memperlihatkan adanya perbedaan yang berarti. Secara umum dapat terlihat dari garis postest pada kelompok eksperimen berada di atas kelompok kontrol. Jumlah jawaban yang benar masing-masing pertanyaan pada kelompok eksperimen lebih tinggi dibandingkan dengan kelompok kontrol. Sehingga dapat ditarik kesimpulan, bahwa pemberlakuan pembelajaran model CTL dengan memanfaatkan lingkungan sebagai sumber belajar dapat meningkatkan hasil belajar siswa.

Analisis komparatif digunakan untuk mengetahui apakah terdapat perbedaan antara peningkatan hasil belajar kelompok eksperimen dan kelompok kontrol. Pengujian dimaksud meliputi: uji kenormalan pretes dan postest, uji homogenitas varians pretes dan postest, dan pengujian hipotesis dengan T-test statistik. Analisis ini dimulai dengan menentukan gain selisih antara pretes dan postes pada masingmasing kelompok eksperimen dan kontrol untuk mengetahui peningkatan hasil belajar siswa.

Untuk mendapatkan informasi mengenai respon siswa terhadap pembelajaran IPS yang menggunakan CTL dengan memanfaatkan lingkungan sebagai sumber belajar dibandingkan dengan pembelajaran konvensional, maka dibutuhkan data pengisian angket oleh siswa. Angket tersebut diberikan kepada siswa baik di kelas kontrol (pembelajaran konvensional) maupun di kelas eksperimen (pembelajaran dengan CTL), setelah kegiatan pembelajaran selesai dilaksanakan. Aspek-aspek respon dijabarkan dalam 24 indikator yang terdiri dari aspek konstruktivisme, inquiry, bertanya, masyarakat belajar, pemodelan, refleksi, dan penilaian yang sebenarnya. Pengisian instrumen ini diisi sendiri oleh siswa tanpa menyebutkan nama supaya hasilnya lebih obyektif.

Respon siswa terhadap pembelajaran konvensional, dapat dideskripsikan (1) 19 siswa tidak setuju bahwa pelajaran di sekolah sering dihubungkan dengan pengalaman-pengalaman baru berdasarkan pada pengalaman siswa sebelumnya, (2) 19 siswa tidak setuju bahwa pengalaman belajara yang diperolehnya bermanfaat, (3) 21 siswa tidak setuju bahwa mereka mendapatkan informasi baru, (4) 17 siswa yang tidak setuju bahwa pelajaran yang diperoleh sendiri dari kegiatan mengamati, bertanya, menganalisa dan merumuskan teori, baik secara individu maupaun kelompok, (5) 15 siswa yang tidak setuju bahwa pelajaran yang diperoleh mengembangkan berpikir tingkat tinggi, (6) 15 siswa yang tidak setuju bahwa pertanyaan yang digunakan oleh guru membimbing mereka untuk berpikir, (7) 17 siswa tidak setuju bahwa pertanyaan yang digunakan guru membimbing mereka untuk menemukan informasi, (8) 21 siswa tidak setuju bahwa mereka suka bertanya, (9) 20 siswa yang tidak setuju bahwa pertanyaan mereka berguna dalam memahami pelajaran, (10) masing-masing 19 siswa tidak setuju dan 4 siswa sangat setuju bahwa pertanyaan mereka dapat menginformasikan pengetahuan, (11) 20 siswa tidak setuju bahwa mereka suka berdiskusi dan bercerita tentang pengalaman belajar dengan teman, (12) 16 siswa tidak setuju bahwa bekerjasama dengan teman dapat menciptakan suasana belajar yang lebih menyenangkan dibandingkan dengan belajar sendiri, (13) 18 siswa tidak setuju bahwa mereka bisa berdiskusi dan mencari informasi bersama teman tentang suatu objek, (14) 13 siswa tidak setuju bahwa guru mereka senang mengungkapkan cara mengajarnya, (15) 18 siswa tidak setuju bahwa guru mereka biasa memperagakan bagaimana beliau menginginkan siswanya untuk belajar, (16) masing-masing 8 dan 0 tidak setuju dan sangat tidak setuju bahwa guru mereka biasa melakukan apa yang beliau inginkan agar mereka melakukan sesuatu, (17) 18 siswa yang tidak setuju bahwa mereka biasa berpikir tentang apa yang telah mereka pelajari, (18) 19 siswa yang tidak setuju bahwa mereka dan gurunya biasa menanggapi kejadian, kegiatan, dan pengalaman sehari-hari, (19) 11 siswa tidak setuju bahwa mereka biasa mencatat apa yang telah mereka pelajari, (20) 16 siswa yang tidak setuju bahwa mereka dan teman-temannya biasa berdiskusi, (21) 17 siswa yang tidak setuju bahwa mereka dan teman-temannya biasa membuat hasil karya/seni, (22) 14 siswa tidak setuju bahwa guru mereka biasa menilai pengetahuan dan keterampilan mereka, (23) 16 siswa yang tidak setuju bahwa guru mereka mengharuskan kepada siswanya untuk menerapkan 
pengetahuan dan keterampilan yang dimilikinya, (24) 17 siswa yang tidak setuju bahwa guru mereka memberi tugas yang kontekstual.

Untuk mengetahui prosentase (\%) respon siswa, maka tiap aspek yang muncul dibagi dengan jumlah siswa kemudian dikali 100\%. Prosentase hasil respon siswa terhadap pembelajaran CTL dan terhadap pembelajaran konvensional dibuat diagram batang.

\section{KESIMPULAN DAN SARAN}

Dari hasil penelitian yang dilakukan di lingkungan SMP Yadika Bangil pada periode Maret-Mei 2017 ini dapat ditarik beberapa kesimpulan, yakni pembelajaran yang menggunakan CTL dalam pembelajaran IPS dapat meningkatkan hasil belajar siswa. Hal ini dibuktikan dari hasil pengujian bahwa Hasil Belajar Siswa yang mengikuti pembelajaran dengan menggunakan metode pembelajaran CTL lebih tinggi daripada hasil belajar siswa yang menggunakan konvensional.

Penelitian ini juga menjelaskan bahwa respon siswa terhadap pembelajaran CTL adalah setuju jika materi selanjutnya menggunakan pembelajaran CTL yang memanfaatkan lingkungan sebagai sumber belajar IPS, artinya siswa memberikan tanggapan yang positif terhadap pembelajaran CTL yang memanfaatkan lingkungan sebagai sumber belajar.

Selain itu aktifitas belajar siswa yang mendapat perlakuan model pembelajaran CTL yang memanfaatkan lingkungan sebagai sumber belajar lebih baik dibandingkan dengan aktivitas belajar siswa yang mengikuti pembelajaran konvensional.

Di Indonesia, sekolah merupakansalah satu institusi pendidikan formal yang memiliki tanggung jawab keilmuan dan tanggung jawab moral untuk menanamkan karakter bagi peserta didiknya. Sehingga dalam melakukan sistem belajar mengajar, sekolah harus menggunakan metode pengajaran yang dianggap lebih efektif dan efisien tanpa mengurangi kenyamanan para peserta didik. Dari beberapa aktivitas penelitian yang dilakukan peneliti pada para siswa, saran yang dapat diberikan peneliti agar dapat menunjang Sistem Belajar Mengajar di lingkungan internal sekolah antara lain.
1. Berdasarkan hasil belajar yang telah dicapai dengan pembelajaran CTL yang memanfaatkan lingkungan maka CTL dapat dijadikan salah satu alternatif dalam pembelajaran, sehingga akan terwujud kondisi pembelajaran yang efektif.

2. Agar respon siswa dalam pembelajaran lebih menarik dan bermakna, maka guru harus kreatif dan inovatif sehingga proses pembelajaran lebih menyenangkan dan bermakna bagi siswa.

3. Dalam penerapan metode pembelajaran CTL yang memanfaatkan lingkungan, sumber belajar tidak hanya bersumber pada buku teks yang tersedia tetapi lingkungan dan nara sumber juga bisa digunakan sebagai sumber belajar sehingga keterlibatan dan aktivitas siswa dapat dioptimalkan.

\section{DAFTAR RUJUKAN}

Alwasilah, Chaedar. 2008. Contextual Teaching \& Learning. Bandung: MLC.

Akbar, S. \& Hadi, S.. 2002. Pengembangan Kurikulumdan Pembelajaran Ilmu Pengetahuan Sosial (IPS). Yokyakarta: Cipta Media.

Arikunto, S. 2010. Prosedur Penelitiansuatu Pendekatan Pratik. Jakarta: PT RinekaCipta. Creswell.W.J. 2010. Research Design Pendekatan Kulaitatif, Kuantitatif, dan Mixed. Jogyakarta: Pustaka Pelajar.

Dahar, R. W. 1998. Teori-Teori Belajar. Bandung: Departemen Pendidikan dan Kebudayaan. Depdiknas. 2003. Kurikulum 2004 Standar Kompetensi Mata Pelajaran Pengetahuan Sosial SMP dan MTS. Jakarta.

Departemen Pendidikan Nasional. 2005. Peningkatan Mutu Pendidikan Dasar melalui MBS, Peran serta Masyarakat, PAKEM (bahan pelatihan 1,2, dan 3). Madiun.

Enoh, M. 2004. Implementasi CTL dalam Kurikulum Berbasis Mata Pelajaran Geografi. Jurnal Ilmiah Pendidikan. Malang: Universitas Negeri Malang.

Gagne, dkk. 1979. Principles of Instructional and Theory of Instruction. Holt, Rinehart and Winston Inc: Canada. America

Johnson, E. 2009. Contextual Teaching and Learning. Terjemahan oleh Ibnu Setiawan. Bandung: MLC. 
Hariyani, L. Y. 2009. Penerapan Pembelajaran CTL dalam Rangka Meningkatkan hasil Belajar Siswa.Skripsi tidak diterbitkan. Surabaya: JTeknik Fakultas Teknik UNESA.

Hasdiana. 2013. Pengaruh Pembelajaran Kontekstual pada Materi Pelestarian Lingkungan Hidup dalam Pembangunan Berkelanjutan terhadap Hasil Belajar Siswa di SMA Negeri 2 Tarakan. Tesis, Program Magister Pendidikan, Universitas Negeri Surabaya, Tidak diterbitkan.

Hasnawati. 2006. Pendekatan CTL Hubungannya dengan Evaluasi Pembelajaran, Jurnal Ekonomi \& Pendidikan. Yogyakarta: Universitas Negeri Yogyakarta.

Hasruddin. 2009. Memaksimalkan Kemampuan

Berpikir Kritis Melalui Pendekatan Kontekstual. Jurnal Tabularasa. Medan: Universitas Negeri Medan.

I Nyoman Gita. 2007. Implementasi Pendekatan Kontekstual Untuk Meningkatkan Prestasi Belajar Matematika Siswa di Sekolah Dasar. Jurnal Penelitian dan Pengembangan Pendidikan. Singaraja: UNDIKSHA.

Merta, M. 2013. Pengaruh Model Pembelajaran Kontekstual terhadap Penguasaan Konsep Koloid dan Sikap Ilmiah Siswa. Jurnal Pendidikan dan Pengajaran. Singaraja: UNDIKSHA.

Muchith, S. 2008. Pembelajaran Kontekstual. Semarang: RaSAIL Media Group

Mutakin A. 1995. Dasar-dasar Pengorganisasian Program Pengajaran IPS SMP. Bandung: FPIPS.

NCSS. 1994. Expectation of Excellencellence: CuryikulumStandars of Social Studies (Washinton).

Nasution. 2011. Kajian Pembelajaran IPS di Sekolah. Surabaya: Unesa University Press.

Nur, M. 2000.Strategi-strategi Belajar. Surabaya:UniversitasNegeri Surabaya
Press.

Sadiman. 2001. Perencanaan Pengajaran. Jakarta: Raja Grafindo Persada.

Sadun, A. dan Hadi, S. 2010. Pengembangan

Kurikulum dan Pembelajaran Ilmu Pengetahuan Sosial (IPS). Malang: Cipta Media.

Sapriya. 2009. Pendidikan IPS Konsep dan Pembelajaran. Bandung: PT PT Remaja RoSMPakarya.

Sugiyono. 2009. Metode Penelitian Kualitatif, Kuantitatif, dan RED. Jakarta: Alfabeta.

Sumaatmadja, N. 1986. Pengantar Studi Sosial. Bandung: Alumni.

Sumaatmadja, N. 1993. Tuntunan Metodologis bagi Pendidikan dan Pembinaan Guru IPS. Jurnal Pendidikan Ilmu Pengetahuan Sosial 2. Bandung: FPIPS IKIP Bandung.

Supriyanto. 2004. Model Pembelajaran Ekonomi di Sekolah Menengah Berdasarkan Kurikulum Berbasis Kompetensi. Jurnal IPS dan pengajaran: Ilmu Pengetahuan Sosial, tahun 38 No.3. Malang; Universitas Negeri Malang.

Sutrisno. 2013. Pengaruh Metode Pembelajaran CTL Pada Mata Pelajaran IPS Materi Pelajaran Perubahan Sosial Budaya Terhadap Hasil Belajar Siswa, Tesis, Program Magister Pendidikan, Universitas Negeri Surabaya, Tidak diterbitkan.

Soemantri, NM. 2001. Menggagas Pembaharuan Pendidikan IPS. Bandung: PT Remaja RoSMPakarya.

Syah, Muhibbin. 2003. Psikologi Belajar. Jakarta: Raja Grafindo Persada.

http:/ / bandono.web.id. 2008. Menyusun Model Pembelajaran CTL. Diakses 20 Januari 2012.

http:/ / pakguruonline.pendidikan.net. 2008. Pendekatan Kontekstual. Diakses 20 Januari 2012.

http://id.wikipedia.org/wiki/

Bangil,_Pasuruan. Diakses 15 Mei 2013. 
34\| Harry Surahman, Pembelajaran Model Contextual Teaching ..... 